\section{The Oldest Banded Iron Formations(BIFs) in Yangtze Craton: the Geochronology and Geochemical Characteristics of Mesoarchean Dujiagou BIFs.}

\author{
HANG ZHOU JR ${ }^{1}$, WENXIAO ZHOU JR. ${ }^{2}$, YUNXU WEI
}

SR. ${ }^{3}$, BO HUANG JR. ${ }^{1}$, DONG FU JR. ${ }^{1}$ AND ZHOU ZHOU JR. ${ }^{4}$

${ }^{1}$ China University of Geosciences(Wuhan)

${ }^{2}$ China University of Geosciences (wuhan)

${ }^{3}$ Wuhan Center of China Geological Survey

${ }^{4}$ The seventh Geological Brigade of Hubei Geological Bureau

Presenting Author: zhouwenxiao@cug.edu.cn

The Northern Kongling Terrane (NKT) as the oldest part of Yangtze Craton, reserved crucial geological environment information of early Earth. The Dujiagou Banded iron formations (BIFs) are disintegrated from Mesoarchean Dongchonghe tonalite-trondhjemite-granodiorite gneisses and Yemadong metasedimentary sedimentary - metavolcanic rock, which constituted the metamorphic basement of NKT. Here, we present geochronological, geochemical and iron isotopic data of the Dujiagou BIFs for the first time to constrain their age, origins and source characteristics, and then discuss their paleoenvironmental implications. As the BIFs are mainly associated with meta-intermediate to acidic rocks and quartz-rich schists, and can be classified as Algoma-type BIFs (Fig.1). U-Pb dating of detrital zircons from an inner volcanic interlayer of magnetite quartzite demonstrate the Dujiagou BIFs formed at the latest ca. $2899 \pm 7 \mathrm{Ma}$ and were affected by Neoproterozoic thermal metamorphism at $825 \mathrm{Ma}$ (Fig.2 a, b). Most BIFs samples dominant high contents of $\mathrm{SiO}_{2}+\mathrm{Fe}_{2} \mathrm{O}_{3}{ }^{\mathrm{T}}$ (average 90.59 wt.\%) and extremely lower contents of $\mathrm{Al}_{2} \mathrm{O}_{3}+\mathrm{TiO}_{2}$ (average 1.01 wt.\%) suggests indicating that they are detrital-free deposits. After normalized by the Post Archean Average Shale (PAAS)[1], the detritus-free BIFs samples are characterized by depleted light rare earth elements, weakly positive La and $\mathrm{Y}$ anomalies, and enrichment in heavy rare earth elements; suprachondritic $\mathrm{Y} / \mathrm{Ho}$ ratio (27.42), resembling geochemical features of modern seawater (Fig. 2 c, d). Cerium shows a weakly negative anomaly; this distribution is fully compatible with that of other Early Precambrian BIFs, indicates low oxygen fugacity in the paleoocean system. Compared with the typical Early Precambrian Algoma-type BIFs, partial trace elements and $\sum$ REE in the Dujiagou BIFs are about one order of magnitude higher; The weak to moderate positive $\mathrm{Eu}\left(\mathrm{Eu} / \mathrm{Eu}^{*}=0.87-1.16\right)$ anomaly indicates the ore-forming fluid is a mixture of low temperature hydrothermal input of yttrium (REY) into seawater rather than high temperature hydrothermal. Positive $\delta^{56} \mathrm{Fe}$ of the BIFs ranges from $+0.26 \%$ to $+0.45 \%$, indicate that only part of $\mathrm{Fe}^{2+}$ in reduced iron seawater was oxidized to $\mathrm{Fe}^{3+}$ in the Mesoarchean low oxygen fugacity environment.

[1]Taylor S R, McLennan S M(1985), The continental crust: its composition and evolution.

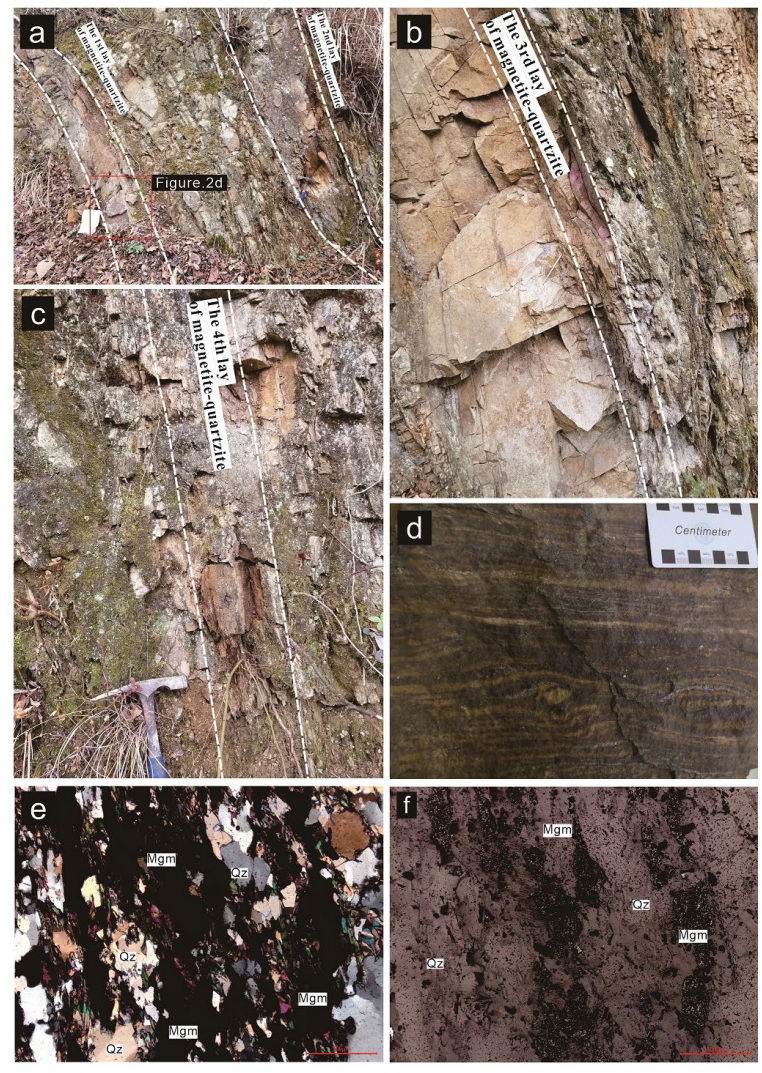

Fig.1. Representative photographs of the Dujiagou BIF. (a-c) Field photographs showing the outcrop of Dujiagou Algoma-type BIFs interbedded with felsic metavolcanic rocks. (d) Banded magnetite quartzite composed of bands of magnetite (dark colored) and quartz (whitc). (e-f) BIF mainly consisting of alternating Fe-oxide (magnetite) and quartz bands with minor other minerals locally (e-Polarized Light; $\mathbf{f}$ - Reflected Light).
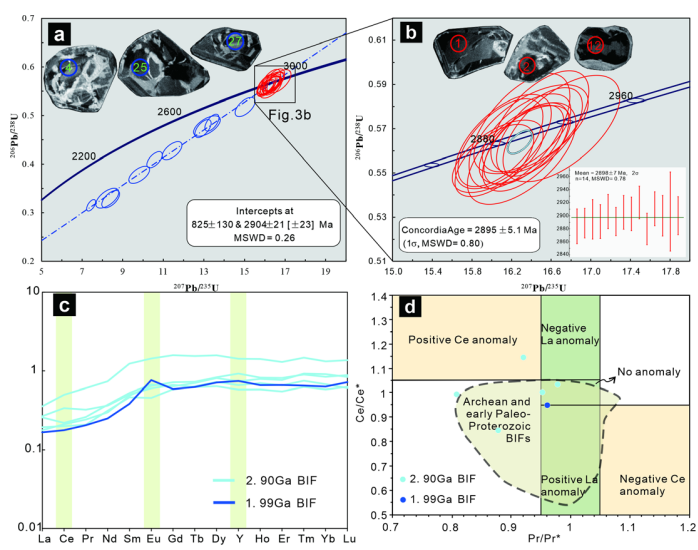

Fig.2. The Chronological and geochemical characteristic diagrams of the Dujiagou BIFs. (a) The zircons are mostly subcircular, ranging in size from 80 to $150 \mu \mathrm{m}$ in length with length/width ratios ranging from 1 to 1.5 , and commonly morphological characteristics of detrital zircons. Zircon U-Pb concordia diagrams show. Twenty-four points draw a discordant line and yield an upper intercept age at $2904 \pm 21 \mathrm{Ma}$ and a lower intercept ages at $825 \mathrm{Ma}$; (b) Fourteen points on the concordia line yield a weighted mean age of $2898 \pm 7 \mathrm{Ma}$; (c) in Post Archean Average Shale normalized REE partiton diagram, the BIFs samples are characterized by depleted LREE, weakly positive $\mathrm{La}$ and $\mathrm{Y}$ anomalies, and enrichnent in heavy rare eath elenent; (d) In $\mathrm{Ce} C \mathrm{Ce}^{*} \mathrm{P} / \mathrm{P}^{*}$ " diegr, an samples are distributed in Archean and early Paleo-Proterozoic BIFs area. 